\title{
ПОРФИРИНОВЫЕ СОЕДИНЕНИЯ ПЕРСПЕКТИВНЫЕ ДЛЯ ФОТОИНАКТИВАЦИИ ГРАММ-ОТРИЦАТЕЛЬНЫХ БАКТЕРИЙ
}

\author{
С.А. Сырбу ${ }^{1}$, А.Н. Киселёв ${ }^{1,2}$, М.А. Лебедев ${ }^{1,2}$, Р.Ф. Чанышева ${ }^{1,3}$, Е.С. Юрина1 \\ ${ }^{1}$ Институт химии растворов Российской академии наук, \\ 153045, Россия, г. Иваново ул. Академическая, д. 1. \\ ${ }^{2}$ Ивановский государственный химико-технологический университет, \\ 153000 , Россия, г.Иваново, пр. Шереметевский, 7. \\ ЗПриволжский исследовательский медицинский университет \\ 603005, Россия, г. Нижний Новгород, пл. Минина и Пожарского. д.10/1.
}

DOI: 10.19163/MedChemRussia2021-2021-527

E-mail: yurina_elena77@mail.ru

Низкая селективность связывания фотосенсибилизатора с целевым субстратом и инициация окисление биомолекул по типу II (образование синглетного кислорода) существенно снижает возможности методов ФДТ и аФДТ, так как развивающаяся гипоксия опухоли или воспалительного процесса приводит к снижению количества кислорода и, соответственно, снижению эффективности первичных фотохимических реакций. В связи с этим актуальной проблемой является конструирование и направленный синтез тетрапиррольных макроциклических соединений для использования их при фотоинактивации патогенов в кислород-независимом режиме.

Скрининг широкого ряда порфиринов, содержащих различные по природе заместители, позволил предложить перспективные для кислороднезависимой инактивации грамм-отрицательных бактерий (см. рисунок).

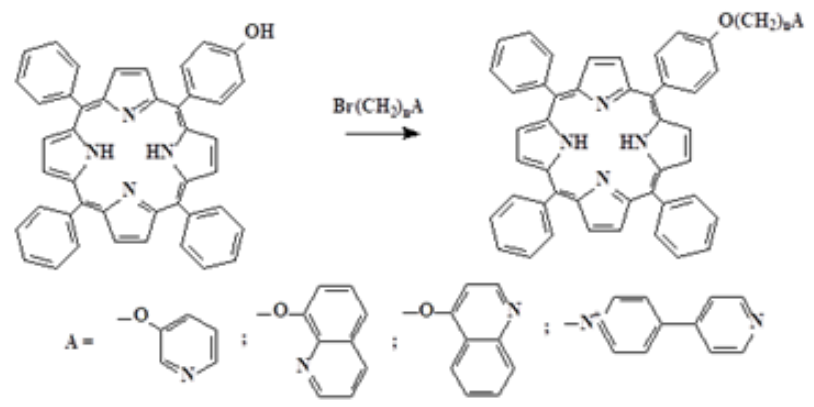

В рамках работы над проектом РНФ №21-73-20140 проводятся комплексные исследования, направленные как на разработку и оптимизацию методик синтеза целевых порфириновых соединений, так и их исследования invitro и invivo. В докладе представлены сведения о влиянии несимметричных пиридилсодержащих порфиринов на свойства липидной оболочки грамм-отрицательных бактерий в темновой фазе и при фотооблучении, а также на жизнеспособность патогена при фотовоздействии.

Работа выполнена при финансовой поддержке РНФ (№21-73-20140). 